F. R. CONTRERAS

Universidad de Sevilla

fmedina@us.es

PEDRO ANTONIO HELLIN ORTUÑO

Universidad de Murcia

phellin@um.es

\title{
Media Aesthetics
}

Two Examples in the Spanish Art

vol 18 / Jul.2018 127-146 pp Recibido: 20-01-2018 - revisado 15-02-2018 - aceptado: 03-03-2018

Arte y políticas de identidad @ Copyright 2012: Servicio de Publicaciones de la Universidad de Murcia. Murcia (España) ISSN edición impresa: 1889-979X. ISSN edición web (http://revistas.um.es/api): 1989-8452 


\section{ESTÉTICA DE LOS MEDIOS \\ DOS EJEMPLOS EN EL ARTE ESPAÑOL}

\section{ABSTRACT}

This article unveils an aesthetic based on the intervention of machinery into creative art procedures. The study goes deeply into a machine-related aesthetic from philosophic reflections, which range from the incursions of, firstly, optical technologies (photography, cinematography) and then electronic technologies (videograph, computer graphics, networks). The research throws new light on the notion of Media Art. The media have opened up to artists the possibilities of the laboratory for aesthetic experimentation and the innovative inter-relationship of art, science, and technology.

In this sense, the text demonstrates how new media creativity experiments with forms more representative of postmodern thinking. For the purposes of a better exemplification of the question raised, this article has briefly analysed the works of two Spanish artists, representative of the two different phases. The first example opens with the commencement of an incipient Media Art in the technological and mystical ruminations of José Val del Omar. In the second example, the contemporary evolution into internet experimentation of Antoni Muntadas is demonstrated.

\section{Keywords}

Aesthetic, Art, Machine Intervention, Technology, Postmodern Period, Culture.

\section{RESUMEN}

Este artículo descubre una estética basada en la intervención de las máquinas en los procedimientos creativos del arte. El estudio profundiza en una estética del maquinismo desde la reflexión filosófica, que abarca desde la incursión de las tecnologías ópticas (fotografía, cinematografía) a las tecnologías electrónicas (videografía, computer graphics, redes). La investigación aporta nuevas luces sobre la noción del Media Art. Los medios han abierto a los artistas las posibilidades del laboratorio de experimentación estética entre arte, ciencia e innovación tecnológica. En este sentido, el texto demuestra como la nueva creatividad mediática ensaya formas más representativas del pensamiento posmoderno. Para una mejor ejemplaridad de la cuestión planteada, el artículo ha analizado brevemente las obras de dos artistas españoles representativos de momentos distintos. En el primer ejemplo, se expone el comienzo de un incipiente Arte de Medios en la cavilaciones tecnológicas y místicas de José Val del Omar. En el segundo ejemplo, se muestra la evolución contemporánea en el ensayo con Internet de Antoni Muntadas.

\section{Palabras Clave}

Estética, arte, maquinismo, tecnología, posmodernidad, cultura. 


\section{BRIEF INTRODUCTION TO THE MEDIA ART}

The evaluation of Media Art begins within a global, technologised society that is accustomed to modern media, with a consumer lifestyle model within the framework of post-modernist culture. Media Art is machine art. In this modern age, it begins with the photographic camera and photographic art. It is not a matter of artistic style or movement; but rather and currently, procedural concepts of art work. In this sense photography will open artistic recognition to other manifestations such as the seventh art; cinematography. Beginning from these modes of the construction of realities, art has experimented with the telephone, fax, neon or fluorescent tubes, radio, television, satellites, video, computer, or current systems of kinetic simulation (or movement sensors).

Media Art not only uses machinery in the realization and the execution of its creations; but rather, it is an art tightly linked to scientific and technological advances. Works of Media Art appropriate the success of industrial engineering, of theoretical science and of humanistic investigation in new expressions of the aesthetic. It is not only a process of orchestration of the very same artistic practice which is abandoning conventional practices of painting, sculpture, music, dance, literature or theatre. Art evolves on the crossroads with science, with the refreshment of the already-existing, in creative innovation or in the re-discovery of the worth of the unique, in abstraction as a route to knowledge of the world, and even, in the idea of the universality of its production.

If science responds to "Why?", technology obeys rather the question of "How?". In art the replies to these questions have given rise to a process of reducing the importance of the outward appearance of the work itself. Progressively more virtual, by reason of its informational and telematic nature, technology allows for experimentation in art, while in science, it facilitates the demonstration of principles. Art and technology have needed a period of understanding and reconciliation since, traditionally, they have been respectively considered as superior and inferior activities. In the beginnings of western culture, Egypt and Greece deemed technology and the work of lower-ranked slaves and artisans, as being inferior. Curiously, this consideration still prevails in the current environment.

Media Art has stimulated changes in aesthetic thinking. Also, with the same Kantian pretensions of arriving at a theory of pure art, Media Art has developed models closer to the Wagnerian concept of Gesamtkunstwerk. Not only in the German romanticism of the past but also, as will be seen later on, in contemporary art, the unique creation is sought; although with the proviso that the aspiration of the learned Kant was to pursue pure beauty. Other thinkers of the $20^{\text {th }} \mathrm{C}$. such as Norbert Wiener, Max Bense or Abraham Moles laid the foundations of an informational aesthetic, or a cybernetic aesthetic, in which the value of communication was more relevant. In this sense, it has been the freeing-up of taste which has really put an end to the extreme positions of an ideology which supports the inferior nature of materials and the rejection of industrial or machinery participation; as opposed to, the nobility of the arts.

Finally, and no less interesting, there has always been the social revolution caused by a popular class who wants to benefit from the intellectual developments of engineers. The marriage between art (the creation of a work) and industry (its production) disgorges into numerous practical experiences of which neither the elite classes, nor the popular classes, want to be without. In these experiments, their ideals take on real form. Art was the way of elevating 
their imaginary universes. Moreover, during the $19^{\text {th }} \mathrm{C}$. machines increased the aspirations of a society for leisure as a cultural challenge of whatever civilization. In this way, the Freudian Marxism of Herbert Marcuse links the superstructure with the aesthetic; by means of the postponement of the commencement of pleasure and, as a result, mankind is thereby forced to submit to the production demands of modern times.

Below, there is work on those aspects which are considered to begin to consolidate themselves into a theory for an art between postmodernism and the technological progress of the current world. Because of its philosophical and artistic character, this exploration is framed within a humanistic perspective based on the reflection about four issues - (1) the meaning of Media Art; (2) the current link between art and technology, (3) its forms of institutionalization; and (4) the relationship it maintains with other disciplines. For that purpose, this investigation is based on a bibliographic research and on philosophic, historic and artistic documentation. Techniques of reading, of analysis and of commentary of texts have been developed and, in addition, procedures of philosophic, communicative and social writing. Some texts have stood out more prominently and their ideas have been followed more closely in this study (Aracil, 1998; Berenguer, Van den Boom, Català Domènech, Costa, Couchot, Giannetti, Jiménez, Hershman, Le Grice, Machado, Millares, Muntadas, Rossler, Shaw, Wagensberg, Weibel y Zielinski, 1997; Connor, 2002; Crespo Fajardo, 2013, Ferry, 2012; Francastel, 1990; Guasch, 2000; González Manrique, 2008; Gubern, 2004; Kittler, 2012a; Kittler, 2012b; Lucie-Smith, 2006; Machado, 2000; Marchán Fiz, 2010; Weibel, 1996). Some texts have stood out more prominently and their ideas have been followed more closely in this study (....). What is more, this research has been rounded off with other studies which relate art and technology. (Brown, Barker and Del Favero, 2011; David, Bogart and Pasquier, 2013; Dumitriu and Whitby, 2011; Halpern, and Star Rogers, 2013; Ilfeld, 2012; Kaipainen, Ravaja, Tikka, Vuori, Pugliese, Rapino and Takala, 2011; Llobera, Blom, and Slater, 2013; Stern, 2011; Utterson 2013; Wu, Selvadurai, Smithwick, Cain, Cavallerano, Silver and Goldring, 2012; Yoon, Song, and Kim 2013; Zhang, Harrell, and Ji 2012; Zoran and Buechley, 2013). The two Spanish artists have been selected by reason of their internationally recognised prestige. The works are paradigmatic examples of the object of this study: the aesthetics of machine intervention into contemporary art. Moreover, they each represent distinct periods in Spanish art history: firstly, Val del Omar's research into the relationship between aesthetics and technology and then the contemporary period, and its experimentation with the new media through the works of Antoni Muntadas.

\section{MECHANISATION IN ART}

Mechanization implies a change in the perceptive and intellectual aptitudes of modern artists. Although the Greeks express the sense of sight through a system of reducing space to squares or grids, or a reticulated system, which gives surface order to the facades of their constructions, to the organisation of background and to the figure in mosaic, or to the proportioning of a sculpture, the modern artist introduces the appraisal of movement and action by means of mechanisation.

During the Renaissance, art advanced with scientific discoveries which show a reality sustained by means of a system of dimensions and relationships which give order to the universe. Nature is discovered as a collection of forces which respond to new concepts and which offer themselves as a surprising spectacle for artistic reproduction. The Renaissance man built so as 
to learn. Moreover, the abandonment of Christian imagery intellectualises his work; through the use of other stories, myths and rituals. The world displays itself to the modern artist without the influence of God. Facts or deeds are presented by means of a different mythology which manages to represent the Renaissance man's life through history and poetry. The artistic transfiguration simultaneously survives with new mental mechanisms which give rise to the printing press in the middle of the $15^{\text {th }} \mathrm{C}$. The mechanical reproduction of texts shows poets the beauty of machinery. Nevertheless, the machine seems to make realities of whatever it assimilates, while art opens itself to the continuous process of transformation of universal rules, of their imaginings and precise language. The machine, more linked to scientific fact, converts into reality a product whose mode of generation and purpose is known.

Since the Renaissance also, the idea of de-humanisation of the world, through the effect of objects created by machines, has prospered. The ugliness of an incipient industrialisation raises its head timidly in this commencement of modernity, although the first parallels between the progress of mechanisms and aesthetic evolution are also seen. Empirical science of that time discovers its practical realization with machinery, but, at the same time, for those matters which it doesn't manage to resolve, for the profundities of mankind and his world, theoretical scientific explanation continues. Soon enough, in the $16^{\text {th }}$ and $17^{\text {th }} \mathrm{C}$. machinery use is reduced to superficial knowledge and will be banished to the shallow scope of toys and entertainments, instead of being respected as part of a relevant engineering.

The machine has passed through various ages, as Francastel asserts in this quotation:

The first age, then: the machine repeats the movements of man; in the second stage, the machine produces new objects with its own movements; in the third age, it imposes on man movements and objects generated by its own logic, and soon thereafter, by means of procedures such as electro-chemical soldering, the machine will make its own efforts more economical. In the new industrial era, there will no longer be fatigue, neither for the machine nor for man; but there will be, from thereon, a new change of value and appearance of the object. (Francastel, 1990, p.132-133)

The plasticity of an art work offers the human mind new means of exploring art that are very distant from the classic sense. Technology goes beyond conventional activities of painting, sculpture architecture or design. The triumphant industrialization of the $19^{\text {th }} \mathrm{C}$. will alter the public's way of looking at things. It will be guided from the domain of nature's construction to the successful relations between the mind of the spectator and his immediate surroundings. During the Renaissance, art, science and technology were to construct automatons, whilst in the $20^{\text {th }} \mathrm{C}$. The perspective of the theory of automatism introduced by the cybernetic aesthetic will intrude into art. The Renaissance automatons of salons and gardens reproduced the functionality and purpose of Nature: Industrial automatism reduced art to a communicative process and to the volatility of information.

All the artistic movements of the $20^{\text {th }} \mathrm{C}$. cross the scenarios of both science and technique. Here the artists, the scientists and the technologists will discover a strong creative bonding, which, being fine in either practice or theory, will reproduce under the aegis of intellectual structuring. Impressionism generates specific models of light, form and colour; surrealism, for its part, mental models; but none of them were to rival scientific models. Art was to be rationalized in this period and, in the 70's, was to be conceptualized; converting itself logically 
into playful language exercises. The most striking fact is that the Impressionists manage their work by supporting themselves with a methodical observation of empirical science, and the scientists study from a more open speculative view. Again, quoting the ideas of Francastel:

Modernity in 1880 is not the technique in itself, neither is it science nor painting; it is men who put different types of activity to the test; sometimes to the conservative intentions in general of the established social forces, sometimes to a renewed exploration of the undefined field of appearances. It is natural then, that towards this very era, there is to be observed - as much at the plastic thinking level as at that of technical thinking - a metamorphosis that parallels the object. (Francastel, 1990, p.132-133)

This same metamorphosis was also already known in the 18th $\mathrm{C}$. when the construction of robots was separated from the world of toys where it had been confined by the courtiers. In the Renaissance and the Baroque periods, machines still had something of playfulness, magic or surprise, of mannerist spectacle which was lost when the Enlightenment period arrived. The Enlightenment Century was to present the issue of the "man - machine" as a new perspective of mankind. As the prominence of God over mankind disappears, man will be studied as a mechanism of systems and organs which function like the mechanisms of a machine.

Almost everything is going to continue, but everything will be shown to viewers and readers differently now that a relationship between man, science and nature appears to have been established; everything is going to be almost always stripped of the transcendence with which it was created, was offered and received in the two previous centuries. If man is not yet a "microcosm", neither now is the machine a reflection of anything, but rather a pure and simple image of itself and of its mechanism: at most, the image of this new man, whom the most radical Enlightenment had stripped of his soul, and compared him to the cold and perfect mechanism of a watch. (Aracil, 1998, p.19)

Machines establish a visual culture distinct from that established by painting, sculpture and architectural tradition. The procedures for making such, their functioning, purpose and placement are disturbing for the solid cement of art theory, well beyond questions of style. The already-cited author, Francastel, is aware of this dependance which highlights the strong linkage between the history of techniques and the history of aesthetics and of art. Technique facilitates, for the artist, creative possibilities in the configuration of new styles. Nevertheless, machines do not only play a role in the refreshment of these styles, nor even in the creation of new values, and neither do they excel by reason of being only a medium for the artist. Perhaps in spite of that, the machine - (from mechanical watches, mechanical fountains in gardens, robots or mobile sculptures, mechanical calendars, automatic musical instruments, mechanical games or labyrinths, as invented by Charles Babbage, and their consequences on modern engineering) in art has provided imaginative, innovative forms, being based on their functional qualities and on the sensory sensations which they provoke. Below, will be laid out some which have been understood as beginning from the interesting study of Alfredo Aracil (1998) in which he reviews numerous ingenious devices between the Renaissance and the Enlightenment.

a) Movement. Machines reproduced nature's movement. They did it without falling into the alltoo-simple repetitive loop, since it was intended to represent the complexity of reality. In this way, it was possible to give a greater credibility to the spectator who was surprised with this 
imitation of life. Hydraulic or pneumatic movement made possible audacious demonstrations of palace gardens or artificial theatre architecture. There is an example in the patio of dolls or robots in Sevilla's Alcázar in Spain. In the cinema, René Clair maintained that "if there is a cinema aesthetic ...it can be summed up in one word:"Movement". (Kracauer, 1997, 34).

b) Naturalism. Continuing along the same lines, the Renaissance robots seek to move closer to natural phenomena (and even supernatural) in a way that the machine will create virtual worlds or copies of the world with which the spectator would be able to interact. This was achieved with musical apparatus which had a robotic function or with sculptures which reproduce daily scenes; mechanistic movements, or with robotic scenes which perform actions in repetitively fixed theatre. (Aracil, 1998, 40).

c) The Toy or the Playful Mechanism introduces the liking for the unpredictable or the extraordinary and these in turn provide aesthetic qualities to western art; such as multiplicity, deception or spectacle. It was intended to attract the attention of the spectator by means of the re-creation of supernatural myths or magical phenomena and they were used in religious rites so as to add to their mythical quality. These resources were modernized with new optical media for images of the Counter-Reformation and the image of War. On that topic, Kittler (2012) explains, very lucidly, how religion influenced the creative process of imagery through the search for a spiritual interior design which would be able to be achieved with light machines producing optical effects and other sensations different to those caused by painted murals or the sculptures of churches and cathedrals.

d) The Value of "the Unusual". Machines are used by the mannerists for their scientific fundamentals to produce those reflections of a supernatural world.

e) Scientific, Philosophic and Artistic Conceptualization in Creative Processes. This deals with going further than the mechanical; towards the pragmatism of discoveries without falling into excessive abstraction. The men of the Renaissance look, not only for playful and leisure activity in mechanical toys, but they also find in them a way of getting closer to a knowledge of the Universe. This purpose is intensified during the Baroque. Machines are not only for the delight of the spectator, but they make possible the re-creation of the rarities of nature; although that may only be in appearance. For that reason, it is a medium of experimentation which reveals mysteries; as if it was a laboratory dealing with them.

f) The Humanisation of the Machine. This is another quality of technology which has also come about during current lifetimes. The use of machines in the enrichment of humanity was an objective of the Renaissance and of the Baroque, a consequence of the crisis of the Aristotelian concept of the Universe. In spite of this willingness, in those centuries there was a lack of confidence that the mechanization model could be brought into play in the interpretation of the very model of human life.

g) The Art of Appearance. The science of machines allows for the demonstration that, by falsifying reality, it is possible to reproduce something better. It happens with Piero della Francesca who deforms bodies so as to improve the practice of pictorial representation. Nevertheless, the empire of appearances does not only finish here. Western thinking sees itself influenced by this condition of moulding the truth to the world in a way formulated in the work of Machiavelli. The political ethic, as opposed to moral duty, will dictate the working 
conditions depending on the context or on how to fit one's actions to the circumstances. Art will follow the same road of aesthetic, ethical and political appearance up to the new, postmodern, interpretation of similitude; more in line with the mass media era.

One could continue enumerating other machinery qualities learnt from the art of machine invention. Those which have been summarised have been set out because they are contemporary and because of their subsequent effect on new forms of digital art (video art, net art, game art, etc.). All of these continue with the development of modern machines. From photographic cameras to simulating systems of virtual environments, works of art realised with media or machines unfold themselves in the same dilemmas; seeking to hide their nature and at other times showing it with pride. In fact, the romantic prejudice - which opposes the machine as a generator of art, and as therefore being opposed to the emotional intensity of mankind - still prevails. Beginning from the end of the $20^{\text {th }} \mathrm{C}$. the opposite occurs, as is shown in the exhibition of Cybernetic Serendipity (London 1968). Strangely, in that exhibition, there are also presented the same type of artistic machines which, centuries ago, were musical devices, kinetic virtual surroundings, robots and which are now known as interactive robots or sculptures, paintings realized by computer or artificial brains capable of being creative without the intervention of man.

Beginning from the foregoing exposure, a typology can be established of the properties of mechanized art in accordance with its operation:

The degree of automatic operation; feigns reality by means of hydraulic, pneumatic or electronic mechanisms.

$\square$ Optical illusion; represents something by means of optical machines, such as photography, cinema, or television.

$\square$ Acoustic illusion; feigns the presence of something by means of sound recording machines or reproduction of sounds.

$\square$ Sensory immersion; feigns a real world by means of machines which multiply sensory stimuli.

This typology will also allow for the differentiation of stages in Media Art, depending on the state of current scientific development, and being differentiated between:

The artistic stage of physical machines. They work in the art field with their intensity, the movement or their power of material transformation or of energy (basically light and sound).

The artistic stage of digital or informational machines. They transform physical or material reality into information, absorb it into its interior, manage it, preserve it and recover it for its objectives.

All of that allows the viewer to recognize that, during the first European avant-garde movement, only the photograph or cinema could be counted on (a period of optical illusion), and that the stage of an art of immersion would not commence until the development of computerized graphics beginning from the 60 's: to be precise, with Ivan Sutherland's project "Sketchpad: A Man-Machine Graphical Communication System", in 1963.

Beginning from the second half of the $20^{\text {th }} \mathrm{C}$., scene-shifting machines in art find inspiration in the mathematical model, "The Mathematical Theory of Communication" published in 1949 
by Claude Shannon and Warren Weaver, and in the cybernetic theory of Norbert Wiener "Cybernetics or the Control and Communication in the Animal and the Machine" published in 1948; in the development of electronic and computer engineering with names as prestigious as Bill Gates, Vinton Cerf or Steve Jobs. In this race towards the technification of culture, Walter Benjamin, Lewis Mumford or Gilbert Simondon headed the collaborative rise of a media philosophy. In semiotic and aesthetic studies, Max Bense, Frieder Nake, Abraham Moles y Herbert W. Franke stand out. In media studies, the School of Toronto is the most influential with Harold Adams Innis and his disciple Marshall McLuhan, while in the same speciality there are Steina and Woody Vasulka, John Cage, Yvonne Spielmann or Laurie Anderson. In the 60's and 70's, television and video serve as artistic exploration along roads opened by cinema. Beginning from the 90's, the new digital media had transforming effects on art, above all when they combined with internet communication technologies. In this current digital era, pioneer artists discover new routes towards uniqueness; testing theories and machines which allow them to work in a relational and communicative aesthetic.

At this commencement of the 21st C., machines will be used in art, searching (a) the participation of the citizenry in an eagerness for the politicization of art. Another option is the incitement of the political gaze on the art of posthumanist reflections (Haraway, 1995); (b) the co-creation with collaborative technology which achieves the production of collective works, (c) the re-combination which will cross the resultant works of different media (cross media art), and (d) the remix, the artist will reuse existing culture, its objects and works, for the creation of another new one.

\section{EXPERIMENTATION IN ART USING MEDIATIZATION}

It is possible to remain with one consistent idea about artistic work with machines since the Renaissance and up to this current era; experimentation. The intersection between art, science and technology enriches mankind's knowledge about his world through a creativity that is open and free of prejudice. Not only is it physical nature that is investigated, but also human nature itself, that is to say, emotions, feelings, and instincts. The machine has even arrived at the human mind with the first psychoanalytic program, ELIZA, (Joseph Weizenbaum, 1966), capable of confounding the patient with its craftiness. Especially interesting is the study of López de Mántaras Badia, Ramón (2013) in which he highlights the work of investigators in artificial intelligence in musical creativity, such as Herbert Simon and Marvin Minsky. Researchers' attention is captured in this study as engineers search out logarithms which may allow for the improvisation of jazz interpretation GenJam de J. A. Biles (1994), or how they may be aware of the limitation of the musical expression during a machine's musical execution.

Artistic experimentation plumbs the depths of the human mind, seeking to give visibility to the unrepresentable. Luis Buñuel and Salvador Dalí dared to do so with oneiric world of dreams in "El Perro Andaluz" / The Andalusian Dog (1929), generating some spectacular images with the cinematographic camera. These artists conceive a work of art in the unconscious and they conceptualise the surrealistic; an artistic and literary movement of the avant garde.

The 20th C. is the century of communication machines; the speedy rotary press of the written media and the photographic diffusion, radio, cinema, television, video-graphics, and computer graphics or virtual simulation. It is a century of machines that conquer space and time, of automobiles, of high-speed trains, or spaceships which transport men into astral 
space. These change the human perception of space and time when they break the sound barrier. Technological advances are a success in language, logic, mathematics, together with the development of electronic engineering, which allows for the computerization of all human activities. The calculator, or the computer, reduces the world to mathematical formulae and so it becomes cryptic until modern computers unveil it in a more humanistic way, through interface. Humanism is dragged through an interfacial spiral which communicates with men through machines; between machines and between men by means of machines. Interface is understood as the emergence of languages between natural beings and artificial ones.

This same Art feeds itself with these languages, enabling researchers to find, in their own era, machine works (art of artificial intelligence), artworks of mankind made with machines, (computer art), and works of art made between men using machines (participative art between artists connected by internet).

Art is overpoweringly influenced by new mechanistic orchestration; not only in its creative procedures, but also in the artist's thinking. Kittler (1999) already made the very same reflection: "Unser Schreibzeug arbeitet mit an unseren Gedanken..." (p.29) These transformations of artistic thought affect not only the arrangement of the work of art, with the new forms of representation; but rather, these transformations of artistic thought vary iconic, hermeneutic and semiotic perspectives. The machine interposes a new postmodern symbolism and does so with a critical vision of its modern ability to create new canons. Media Art introduces radically new artistic variations, very distant from those closed-to-inspiration and somewhat bourgeoisie. It also revitalises specific myths referring to machinery. Media Art is capable of breaking away from prevailing theory which attempts a harmony of plural points of view. This it does, and it does so through a more nihilistic perspective of the Nietzsche style, in which chaos fits comfortably and in which identity yields to difference and to a new subjectivity. Communication machines generate a meaningful or communicative work, full of relations between the artist, the work and its viewer, and moreover with linkage to its public and institutional context (virtual galleries, internet scenarios).

Art, using machines, has developed its own language. It is the same with record collections (or recorded music), photography or cinematography. Other experimental artistic manifestations have not advanced as much, in the formalization of an exclusive syntax for their particular medium. This is the case of the experimental video as opposed to audiovisual language of video-clip, or of radical, experimental cinema relative to narrative cinema. Industrial systems of exploitation and public consumer tendencies lead to production schemes and narrative models which are repetitive and allow for the rapid recognition of a work; although they also consolidate new artistic styles; (cinema genres, photographic and even musical styles have to be seen in the context of the medium: vocal, acoustic, electric). These styles are based, in Media Art, on two very specific aesthetic positions such as those shown by Kracauer (1997, 28 et seq.). In the first place, it is a realistic art based on the capture of physical materiality or on physical existence, in a way that photography captures. Secondly, it is in the art of life, based more on the suggestion of a universe constructed in the manner of a scenic work, which is self-sufficient either in its performance ability or in classical poetry. Media Art can speak in a Hegelian sense; between thesis and antithesis. The Media work brings together perfection and imperfection only through the decision of the artist in choosing one road or the other for his express purposes. Beyond the general theories of the visual arts, sounds or audiovisuals which support the pre-conception of specific exhibitions, projections or auditions, art has an escape into unknown experiences which enrich the human treasury of his culture. 
And now, beginning with two specific examples of Spanish art, some important reflections will be set out about Spanish Media Art studies. These artists and their works have been chosen using criteria of innovation, uniqueness and their degree of experimentation. They are works which have in common their audiovisual nature, but between them one can observe the difference in the optical stage of cinematographic technology, and another stage, also electronic, but videographic and with connection to Internet.

\subsection{A Media Antecedent in the experimental cinema of José Val del Omar}

This work by Val del Omar (Granada, 1904 - 1982) was begun in 1953 within a project entitled "The Elemental Spanish Triptych". The project as Gubern $(2004,17)$ has documented it, consists of a commencement in Galician mud or clay, to then pass through Castilian furnaces and end up with the Aguaespejo Granadino. From the first photograms, Val del Omar reveals an intention very different from that of the conventional cinematographic, expressing it through titles such as a "short audio-visual essay of lyrical plasticity" and he links his artistic labour to his scientific work which he calls "diaphanous sound". In the short film, "Aguaespejo Granadino", there can be observed an unconventional setting-up which formally breaks with the rules of narrative audiovisual continuity.

This expressive rupture in the work is an appropriate gesture in contemporary art, and very much related to the postmodern spirit. The formal rupture in the narration is very similar to the times of the musical video-clips and of current publicity (audiovisual genre with which he interested himself in the final years of his life and which his work, without a doubt, advanced). In this sense, the narration conserves a relationship with the works realized by others such as Mark Romanek or Chris Cunningham. In the same fashion as the contemporary work of these video artists, Val del Omar has the capability of coming close to popular culture, introducing tradition by way of images of daily life and flamenco music and singing, and the same time, bringing himself closer to a specialised public, in a way that has been extracted from a detailed description which the expert, Roman Gubern, has quoted:

Aguaespejo granadino constitutes a sample of cinematic poetry in its purest state, putting forward a very unique world view of profound mystical and oriental penetration. And it possesses that which pleased him as much as his contemporary, Buñuel; mystery. Look at the brief and enigmatic image of a crucified man on a Saint Andrew's cross in a forest, spied on from the back. In vain will one look for the key to this enigma. Because the films of the mature period of Val del Omar are without their very beautiful audiovisual texts - incomprehensible from a verbal-logic approach, through the word, - their analysis defies us:" This film isn't made to be understood, it flourished so that they might feel it" asserted the author in 1956 in Revista Internacional de Cine». (Gubern, 2004, 54).

Not without reason, Gubern speaks of "meca-mística" (mystic-mecca) in the work of Val del Omar, to express the high point of his use of mechanics in cinema-making, (elsewhere called 'the mechanics of the invisible' or 'where spirituality intersects with science'), since his work profits to the limit from the mechanics of the cinematographic medium. This will be the common 
denominator in the artist's video productions. About this intuition, Connor (2002, 115-126) has reflected in his postmodernism study and notices that narration time on television and video is, on occasions, machine time.

Val del Omar breaks with the uniqueness of art in favour of its multiplicity. "Aguaespejo Granadino" shows the artist's personal view of the Andalusian countryside, culturally typical in a mosaic constructed of fragments from reality. This kaleidoscopic vision, loaded with a certain romantic nostalgia, is of use to him serving to permeate the work with a transitory nature and to shed all permanence. It is a work which dissolves in front of the spectator. It slips out of the hand like beach sand, and there remains only the sensation of warmth and its friction on the skin. It is his way of reflecting on that metaphysic of subjectivity so present among modernity's final works. Man adopts a point of view about the world, beginning with what is considered to be easily manipulated material, able to be dominated and without willpower. This Heideggerian starting point is the birth of individualism in art. The critique of History that goes back beyond man makes of him a being that is timeless, without history and immersed in a cycle of continuous renovation which affects the very history of art. From this point, artists question the control that the weight of history can exercise over their work. It neither helps in overcoming the past, nor in clarifying the present.

Mankind changes with its era, and history does not have that repercussion which even Nietzsche appeared to respect. For Heidegger, one is part of the same history and, like it, one ought to advance, change and modernize, without looking at the mythical or exemplary past. In this judgmental thinking of the pre-modern past, the modern work of art fearlessly breaks with a tradition full of standard fetishes which restrict art to a misunderstood essence. Breaking with rigidity or with the impossibility of innovation, it begins with a new metaphysics of individuals and of subjectivities. The autonomous liberty and sovereignty of the artist will be the drivers of the new avant garde in modern art. This new rational religion of the here-and-now restricts the artist to a criticism of his current time and society. In this same spirit, media artists want to change art with the techniques of the present, in which technique also signifies art; to create something beginning from point zero.

It is this, that can be read in the work of Val del Omar; the spirit of modernity, opening the way for the basis of a technological inventiveness, since the artist is moreover the inventor of cinematographic systems which impel a new, poetic film-making outside of the conventional narrative fiction. For that, and with every justification, González Manrique (2008) recognizes Val del Omar as a modern Renaissance man. In "Aguaespejo Granadino", Manrique calls attention to the artistic daring when innovative resources are used, accelerating time, playing with optical effects, distorting images, selecting photographic range, colouring light, mixing popular texts, romanticism and modernity to end up with artistic norms of personal subjectivity.

Val del Omar achieves a work full of symbolism using the crossing of images of the city of Granada, the gypsies of Sacromonte, water fountains, landscapes of la Alhambra and the Generalife which criss-cross with the experimental game of diatonic sound. The disappearance of a set of absolute values is important in the action of Val del Omar which fits the work into the cultural acceptance of the moment or into the terrain of institutional criticism. Val del Omar's work is fleeting, transitory and also liquid, such as in his water sculptures and the photographed light of the fountains which, in addition, give rise to liquid; Bauman's favourite term for explaining this effect of modernity to his audience. Media Art is to work with the flow of time and with 
non-material elements (of light and information). It produces virtual works which are only fully realised in the process of presentation and can be de-constructed to explore their sense, and even on other occasions, their structure. They are unfinished works which open themselves to an unlimited semiosis or to a bottomless, continuous interpretation. "Aguaespejo Granadino" finally is time, a time projection which can only be contemplated in the moment of its exhibition and to disappear afterwards. Val del Omar predicts, through his film-making work, a period of liquid aesthetics based on the new and on the culturally-discarded or, in the postmodern spiral of continuous creation and destruction, where art now finds itself. His modern work provides machine art with free space so as to deal with the postmodern question from the outside.

\subsection{Current Spanish Media Art of Antoni Muntadas}

To be precise, Media Art was popularized in the 60's when new means of expression were sought. Of all the possible technologies utilized by artists, it is fitting to recognize that the most representative are electronic technology, television and video.

In general it is believed that the key date in this story is the 14th of October 1966, when Robert Rauschenberg, electronic engineer assisting Billy Kluver organized the series "Nine Nights: Theatre \& Technology" in New York's Ninth Regiment Armory. This, in its turn, yielded place to the creation the following year of an organisation called EAT (Experiments in Art \& Technology) with the same collaborators in charge. (Lucie-Smith, 2006, 230)

As Lucie-Smith contends, work with the electronic image coincides with the climate of sexual liberation and of political protest at the end of the 60's and the beginning of the 70's. Then, television was experimented with; searching for alternatives resistant to propagandist activity in the service of the capitalist system and of national governments. Television, the video together with more conceptual artistic practices, such as were the actions, the performances and the happenings, succeeded in the artist abandoning the passivity of the past, and rather occupying the centre of power; politicizing art (in a way that had been foretold by Walter Benjamin at the beginning of the $20^{\text {th }} \mathrm{C}$.)

Video-art should compete with an environment saturated with cinematographic images, taking, from that point, their first artistic references (Faulkner, 2006, 14-19) (Rees, 2005). For Muntadas, the cinema (of directors such as Alfred Hitchcock, David Lynch, Stanley Kubrick, Pier Paolo Passolini, Jean Cocteau, Jean Vigo, Derek Jarman or Peter Greenaway) was influential through the expressive treatment of their images. Lucie-Smith led the way in the video's popularization through projections in museums, galleries and in commercial spaces. Among the pioneer artists, Nam June Paik (1932-2006), Grupo Fluxus, Gary Hill (1951-), Bill Viola (1951-), Grupo Studio Azzurro or Tony Oursler (1957-), stand out. Currently video-art is evolving in formats as radical as Vjing: a term born in the 70's in New York's Peppermint Club lounge with the influence of expressive artists, (Joseph Beuys, Yoko Ono), cinematographers (Edward Muybridge, Sergei Eisenstein, Fritz Lang, Luis Buñuel), musicians (Karlheinz Stockhausen, John Cage, Pink Floyd, Cabaret Voltaire).

In this transformative process, there also began the Spaniard, Antoni Muntadas (Barcelona, 1942- ), who works with television, video and digital art, and more specifically net-art. This multi-media characteristic in Muntadas' work is also seen in other artists such as Chris Marker, artistic director of cinema who completed among his latest projects an interactive compact disc 
entitled "In Memory" exhibited between the $4^{\text {th }}$ of June and the $29^{\text {th }}$ of September 1997 in the Musée National d'Art Moderne, Centre Georges-Pompidou (Dubois, 2006, 139-140). This is a new attribute among contemporary artists, similar to the Renaissance artist, who works in his studio with different media and on diverse objects. It also conforms totally to a tradition among artists who have looked for new collaborative forms among different arts, such as the same notion already cited of the composer Richard Wagner's Gesamtkunstwerk.

It is important to observe that Antoni Muntadas' work shows a media coherence which takes him from working with video to finally creating an Internet project. In spite of its multi-media nature, the unity of the work has the same critical, social and political spirit.

Muntadas, with a vast production of a critical variety, and without personal concessions, has among his works of the 90's one of the Web's classics "The File Room", which takes us back to the question of art censorship and is a good example of a hybrid installation which functions simultaneously on Internet. It is a data bank which collects, on a world-wide scale, cases of art censorship. This working file was presented in numerous artistic demonstrations in the form of a Kafka-type installation, surrounded by walls of piled-up boxes, in which internet-connected video monitors are interspersed. Since its inauguration in 1994, simultaneously in the Chicago Cultural Centre and on the web, The File Room offers internauts the possibility of adding their own examples of artistic censorship on the site which is updated regularly.

In 1995 he started another project "On Translation", made up of more than 40 individual works. "The File Room", as much as "On Translation", supposes the artist's appropriation of the communication media and a legitimization of the value of public space. The artist uses technologies in a sense which is the reverse of their programmed function. For Muntadas, the communication media are conducive of a lethargy which impedes society from having a keen awareness of their continued political, social and moral manipulation. Thus he reverts to his logic in revealing in "The File Room" the censorship and control over free thinking and of an open culture. Internet opens to him, in a new public space, the opportunity of this denouncement of the abuse of power over the media of communication which the artist conquers so as to distance himself from the contaminated scenarios of a culture that is bourgeois and institutional. For the artist, it is a space to practice political resistance (Luna Delgado, 2015). The Hegelian insight is not far away in Muntadas' work. The latter contemplates the necessity of reactivating the awareness of individuals and of freeing up their experiences as consignees of knowledge in favour of their own lives. Art is the liberation of the perceptive route of the final reality. While the communication media use technology to obstruct transparency of information by means of censorship, propaganda and cultural manipulation at a global level, art - for Muntadas - is a place for counter-information resistance. What is more, like other artists of Media Art, he finds the site perfect for experimentation with new artistic contributions.

"The File Room" is a synthesis of the postmodern condition. Muntadas' work, as Guash (2000, 460 ) in a similar way observes, is the sum of tactics and strategies of the fragmentation of texts, the decomposition of the observant look, and of a disintegrating activity on the density of spaces which saturate the hegemonic forces of current society. Muntadas breaks with the information intensity to which viewers are subjected and which impedes those viewers from going out to a place of reflection. Through the fragments which he separates for his readers, he looks for the cultural interstices hidden by the media, political and religious censorship and that belonging to a consumer society which dictates the value of things. On those hidden crossroads, 
the artist finds the unexpected response for the disturbed spectator who admits doubt that opens up to him about the established order.

To resort to the Internet is to travel new horizons. The same feeling that the search for public space has in landscape or in a city, in the plazas o parks, is that which brings Muntadas to work in the net. Internet is already not only a medium for the artist; but rather, a place of confluence of mankind; where opinions and ideas are shared. The new postmodern scenario, which brought an end to the sacredness of the museum or gallery, demands a spectator that is active, alive and curious; quite the contrary to the narcotic action of the mass media. The consulting of the diverse information about censorship which he incorporates into his project, also teaches us, along the lines of Michael Foucault, that history is, after all, a human construction, of which the only matters that are known are those which the powers-that-be want to be known. Likewise, the visible peaks of reality are fabrications as alienated as the rest of industrial production.

In conclusion, Muntadas brings together in his creation a personal vision of reality, the complexity of language games (he makes available to his viewers the means of interpreting them) and an epistemic theory which confronts his readers and viewers in a way that they now have to become acquainted with their own world from the meaningfulness of these artistic discourses.

\section{CONCLUSION}

The machine in art, and Media Art, have supposed the artist's appropriation of the technologies and media of his era; with the intention of conceiving unique works sensitive to their times. Nevertheless, depending on the hegemonic model of society in the historical passage of time, technologies have been used to augment art's productivity (as in recorded music, the video and internet diffusion). Capitalist environments have industrialized art; giving rise to a routine, standardised and serialised production. Profiting from the massive diffusion of pleasant stimuli has created an art of the masses, which does not correspond with the aspirations of Media artists who seek out a unique aesthetic, a political ethic, for the new digital era. To achieve that, to think about the art of machines, is not a reflection, exclusive to technical mediums, instruments or artistic procedures. The mutual coming together of art, science and technology from the beginning of modern times, and now in the late modernity of the $20^{\text {th }}$ and $21^{\text {st }}$ centuries, has improved artistic expression, which now sees itself enriched by the technological and human discoveries of the times.

Artists have worked with the know-how and the impressions of their period, as occurs in the examples of José Val del Omar in cinematography, or Antoni Muntadas, in the multi-media field, of the digital era. This perspective, as a basis of conclusion, does not leave off maintaining a certain relationship with Hegel's notion of art.

Each civilisation develops its own art, and, collectively, always does so at a level superior to the previous. This operation repeats itself because art transmits metaphysical knowledge of the final reality, of the Absolute. For the post-modern era, although the great meta-narratives - such as art, religion or philosophy - have entered into crisis, it is possible to consider that Hegelian thesis of individual improvement through self-awareness enriched with new experiences, as is the case of the actions of these artists. Art is the medium most suitable, thought Hegel, for one to approach the knowledge of human essence, also of self-understanding through perception. 


\section{Bibliografía}

Anderson, Perry. (2005). As origens da Pós-Modernidade. Lisboa: Edições 70.

Aracil, Alfredo. (1998). Juego y artificio: Autómatas y otras ficciones en la cultura del Renacimiento a la llustración. Madrid: Cátedra.

Bauman, Zygmunt. (2007). Arte ¿líquido? Madrid: Sequitur.

Bauman, Zygmunt. (2009). Modernidad líquida. Buenos Aires: Fondo de Cultura Económica.

Berenguer, Xavier., Van den Boom, Holger., Català Domènech, Josep M., Costa, Mario., Couchot, Edmond., Giannetti, Claudia., Jiménez, José., et al. (1997). Arte en la era electrónica. Perspectivas de una nueva estética. Barcelona: ACC L’Angelot.

Boden, Margaret. (1991). The Creative Mind: Myths and Mechanisms. New York: Basic Books.

Brown, Neil C.M., Barker Timothy S., and Del Favero, Dennis. (2011). "Performing Digital Aesthetics: The Framework for a Theory of the Formation of Interactive Narratives", Leonardo, 44 (3): 212-219.

Connor, Steven. (2002). Cultura Postmoderna. Introducción a las teorías de la contemporaneidad. Madrid: Akal.

Contreras, Fernando R. (2012). “Una nueva relación entre el artista y su obra: La obra de arte en la era digital", Revista TELOS (Cuadernos de Comunicación e Innovación), 10: 1-10.

Crespo Fajardo, José Luis. (2013). "Antoni Muntadas. Videocreación e instalación audiovisual”, La Colmena, 79: 43-48.

David, Benjamin, Bogart, Robert and Pasquier, Philippe. (2013). "Context Machines: A Series of Situated and Self-Organizing Artworks", Leonardo, 46 (2): 114-122.

Dikovitskaya, Margaret. (2005). Visual Culture. The Study of the Visual after the Cultural Turn. Cambridge, London: The MIT Press.

Dubois, Philippe. (2006). Recherches sur Chris Marker. Paris: Presses Sorbonne Nouvelle. 
Dumitriu, Anna., and Whitby, Blay. (2011). "Cybernetic Bacteria 2.0", Leonardo, 44 (3): 264-265.

Faulkner, Michael., and D-Fuse. (2006). Vj. Audio-visual art and vj culture. UK: Laurence King Publishing Ltd.

Ferry, Luc. (2012). Homo Aestheticus. A inveção do gosto na era democrática. Lisboa: Edições 70.

Francastel, Pierre. (1990). Arte y técnica en los siglos XIX y XX. Madrid: Editorial Debate.

González Manrique, Manuel Jesús. (2008). Val del Omar. El moderno renacentista. Granada: Fundación Ibn al-Jatib de Estudios de Cooperación Cultural.

Guasch, Ana María. (2000). El arte último del siglo XX. Del posmodernismo a lo multicultural. Madrid: Alianza Editorial.

Gubern, Román. (2004). Val del Omar, cinemista. Granada: Diputación de Granada.

Halpern, Megan K., and Star Rogers, Hannah. (2013). "Inseparable Impulses: The Science and Aesthetics of Ernst Haeckel and Charley Harper", Leonardo, 46 (5): 465-470.

Haraway, Donna Jeanne (1995). Ciencia, cyborgs y mujeres : la reinvención de la naturaleza. Madrid: Cátedra.

Hatfield, Jackie, ed. (2006). Experimental Film and Video. Eastleigh, UK: John Libbey Publishing.

Howells, Richard. (2008). Visual Culture. Cambridge, Malden: Polity Press.

Ilfeld, Etan J. (2012). "Contemporary Art and Cybernetics: Waves of Cybernetic Discourse within Conceptual, Video and New Media Art", Leonardo, 45 (1): 57-63.

Jensen Hines, Thomas. (1991). Collaborative Form: Studies in the Relations of the Arts. Kent, Ohio and London, England: The Kent State University Press.

Kaipainen, Mauri., Ravaja., Niklas, Tikka, Pia., Vuori, Rasmus., Pugliese, Roberto., Rapino, Marco and Takala, Tapio. (2011). "Enactive Systems and Enactive Media: Embodied HumanMachine Coupling beyond Interfaces", Leonardo, 44 (5): 433-438. 
Kester, Grant H. (2004). Conversation Pieces: Community and Communication in Modern Art. Berkeley, Los Angeles, London: University of California Press.

Kittler, Friedrich. (1999). Gramophone, Film, Typewriter. Stanford, California: Stanford University Press.

Kittler, Friedrich. (2012a). Optical Media. Cambridge: Polity Press.

Kittler, Friedrich. (2012b). Literature, media, information systems: essays. Routledge: New York.

Kracauer, Siegfried. (1997). Theory of film. The Redemption of Physical Reality. Princeton, New Jersey: Princeton University Press.

Llobera, Joan., Blom Kristopher J., and Slater, Mel. (2013). “Telling Stories within Immersive Virtual Environments", Leonardo, 46 (5): 471-476.

López de Mántaras Badia, Ramón. (2013). “Computational Creativity". Arbor, 189(764): a082 doi: http://dx.doi.org/10.3989/ arbor.2013.764n6005

Lucie-Smith, Edward. (2006). Os movimientos artísticos a partir de 1945. São Paulo: Martins Fontes.

Luna Delgado, D. (2015). "En torno a the file room de Antoni Muntadas: un ejemplo pionero de ciberartivismo". En Move.Net: Actas del I Congreso Internacional Move. Net sobre Movimientos Sociales y TIC: 218-231.

Machado, Arlindo. (2000). El paisaje mediático: Sobre el desafio de las poéticas tecnológicas. Buenos Aires: Universidad de Buenos Aires.

Marchán Fiz, Simón. (2010). Del arte objetual al arte de concepto (1960-1974). Madrid: Akal.

Martín Prada, Juan. (2012). Otro tiempo para el arte. Cuestiones y comentarios sobre el arte actual. Valencia: Sendemà Editorial.

Prado, Gilbertto. (2005). "Redes y espacios artísticos de intervención". En Estética, ciencia y tecnología. Creaciones electrónicas y numéricas, editado por Hernández García, Iliana, 172-180. Bogotá: Editorial Pontificia Universidad Javeriana. 
Radio Televisión Española. "Entrevista a Antoni Muntadas". Acceso 23 de junio de 2014. http://www.rtve.es/television/20120113/ antoni-muntadas/489198.shtml

Rees, A. L. (2005). A History of Experimental Film and Video. London: British Film Institute.

Schneckenburger, Manfred., Fricke, Christiane., and Honnef, Klaus. (2005). Arte do Século XX. Vol. 2. Köln: Taschen.

Stern, Nathaniel. (2011). "The Implicit Body as Performance: Analyzing Interactive Art", Leonardo, 44 (3): 233-238.

Utterson, Andrew. (2013). "Early Visions of Interactivity: The in (put)s and Out (put)s of Real-Time Computing", Leonardo, 46 (1): 67-72.

Val del Omar's, José. "Otros escritos”. Acceso 30 de junio de 2014. http://www.valdelomar.com/

Weibel, Peter. (1996). "The World as Interface: Toward the Construction of Context-Controlled Event-Worlds". In Electronic Culture: Technology and visual representation, edited by Druckrey, Timothy, 338-343. New York: Aperture.

Wu, Faye., Selvadurai, Chindhuri., Smithwick, Quinn., Cain, James., Cavallerano, Jerry., Silver, Phil and Goldring, Elizabeth. (2012). "The Seeing Machine Camera: An Artistic Tool for the Visually Challenged Conceived by a Visually Challenged Artist", Leonardo, 45 (2): 141-147.

Yoon, Joonsung., Song, Kwanho and Kim, Insub. (2013), “Digital Mandala: The post-virtual as meditation of impermanence or a new reality", Leonardo, 46 (5): 496-497.

Zhang, Kang., Harrell, Stuart and Ji, Xin. (2012), “Computational Aesthetics: On the Complexity of Computer-Generated Paintings", Leonardo, 45 (3): 243-248.

Zoran, Amit and Buechley, Leah. (2013). "Hybrid Reassemblage: An Exploration of Craft, Digital Fabrication and Artifact Uniqueness", Leonardo, 46 (1): 4-10. 
